\title{
Pemanfaatan Limbah Kulit Singkong untuk Produksi Oligosakarida melalui Hidrolisis Kimiawi
}

\author{
Ashadi Sasongko ${ }^{*}$, Deosdado Farrel H Lumbantobing ${ }^{2}$, Agus Rifani $^{3}$, Bangkit Gotama ${ }^{4}$ \\ ${ }_{1,2,3,4}$ Institut Teknologi Kalimantan, Balikpapan, Indonesia \\ *E-mail: ashadisasongko@itk.ac.id
}

\begin{abstract}
Abstrak
Kulit singkong merupakan limbah biomassa yang kaya akan polisakarida. Polisakarida dapat dihidrolisis secara kimiawi dan terkontrol menjadi oligosakarida. Tujuan penelitian ini adalah untuk mempelajari kesesuaian jenis dan konsentrasi asam untuk menghidrolisis, dan menganalisis produk hidrolisis menggunakan spektrofotometer dan kromatografi lapis tipis (KLT). Asam yang digunakan dalam hidrolisis adalah asam klorida, asam sulfat, asam fosfat, asam asetat, dan asam sitrat, dengan konsentrasi 0.3, 0.4, 0.5, 0.6, dan 0.7 molar. Penentuan gula total dilakukan menggunakan metode fenol. Analisis gula pereduksi dilakukan dengan metode DNS. Rasio gula total terhadap gula reduksi digunakan untuk memprediksi derajat polimerisasi (DP). Hampir semua asam dengan konsentrasi masing-masing, menghasilkan DP 2-6. Hasil hidrolisis juga dikonfirmasi menggunakan TLC dan Rf-nya dibandingkan dengan Rf glukosa dan maltosa sebagai standar relatif.
\end{abstract}

Kata kunci: limbah kulit singkong, oligosakarida, hidrolisis kimiawi

\section{Abstract}

Cassava peels are biomass wastes that is rich of polysaccharides. Polysaccharides can be hydrolyzed chemically under control to produce oligosaccharides. The aims of this research are to study the suitability of the type of acids and the concentration of acids to hydrolyze, and analize the hydrolysis product using spectrophotometer and thin layer chromatography (TLC). The acids used in the hydrolysis were chloride acid, sulphuric acid, phosphoric acid, acetic acid, and citric acid, in concentration 0.3; 0.4, 0.5; 0.6; 0.7 molar. Total sugar was determined using phenol method. Analysis of reducing sugar was performed by the DNS method. The ratio of total sugar to reducing sugar was used to predict the degree of polymerization (DP). Almost all of acids with each concentration produced DP 2-6. The results were also confirmed using TLC and the retardation factor (Rf) compared using glucose and maltose as relative standards.

Keywords: cassava peel waste, oligosaccharide, chemical hydrolysis

\section{Pendahuluan}

Singkong merupakan produk yang melimpah di Indonesia. Menurut BPS, pada tahun 2013 produksi singkong di Indonesia mencapai 23.824.000 ton [1]. Sekitar $16 \%$ dari berat singkong adalah limbah seperti kulit dan serat. Pada fraksi berat kering, terdapat protein sebanyak 3,5\%, serat kasar $10 \%$, lignin $11 \%$, selulosa $14 \%$, dan hemiselulosa $27 \%$. Limbah singkong yang kaya akan karbohidrat dapat digunakan untuk produksi bioetanol, kompos, dan pakan ternak.

Karbohidrat pada umumnya dikelompokkan menjadi monosakarida, oligosakarida, dan polisakarida. Menurut IUPAC, oligosakarida merupakan polisakarida rantai pendek yang terdiri atas 3 sampai 9 monosakarida, baik monosakarida penyusunnya satu jenis (homo-oligosakarida) maupun beda jenis (hetero-oligosakarida) [2]. Definisi lain menyebutkan bahwa oligosakarida adalah polimer dengan unit monosakarida sebanyak 2 sampai 10 [3]. Oligosakarida bersifat mudah larut dalam air dan pelarut polar lainnya.

Polisakarida yang bersifat tidak dapat dicerna, dapat dihidrolisis menjadi oligosakarida maupun monosakarida. Oligosakarida kasar sering dimanfaatkan sebagai pakan ternak karena dapat mengaglutinasi bakteri. Beberapa penelitian tentang pakan ternak, memanfaatkan fruktooligosakarida (FOS) untuk memperbaiki pertumbuhan dan meningkatkan efisiensi produksi ayam pedaging. Penggunaan oligosakarida pada pakan unggas sudah umum 
dilakukan di Jepang dan penggunaannya di Eropa terus meningkat [4]. Syahruddin et. al. melaporkan bahwa manno-oligosakarida dapat mengaglutinasi 5 dari 7 strain E. coli dan 7 dari 10 strain Salmonella thypimurium dan Salmonella enteridis [5].

Dalam beberapa tahun terakhir, produk-produk susu formula mulai diperkaya dengan campuran oligosakarida seperti inulin, FOS dan galakto-oligosakarida (GOS) yang berfungsi sebagai prebiotik. Prebiotik bermanfaat untuk mendorong pertumbuhan bakteri menguntungkan dalam usus, sehingga menyehatkan saluran pencernaan dan meningkatkan daya tahan tubuh, khususnya untuk anak-anak yang berada pada masa pertumbuhan. Produk-produk serupa di pasar juga terus bermunculan seiring tingginya tuntutan untuk meningkatkan kualitas kesehatan. Akan tetapi harga produk susu yang diperkaya prebiotik lebih mahal dibandingkan produk susu biasa.

Prebiotik didefinisikan sebagai bahan makanan yang sulit atau tidak dapat dicerna, yang dapat menguntungkan organisme inang dengan menstimulasi secara selektif pertumbuhan \& aktivitas bakteri probiotik dalam usus besar. Bahan tersebut tidak dapat dicerna oleh enzim-enzim percernaan, sifatnya menyerupai serat pangan, sehingga tidak bisa diserap dalam usus kecil, yang pada gilirannya akan masuk ke usus besar. Selanjutnya oligosakarida tersebut akan difermentasi oleh bakteri-bakteri yang menguntungkan di dalam usus besar. Bakteri-bakteri menguntungkan yang dapat distimulasi pertumbuhannya oleh oligosakarida antara lain Lactobacillus dan Bifidobacteria.

Sebagian oligosakarida terdapat secara alami dalam sayur-sayuran dan buah-buahan, sementara sebagian lainnya dapat diperoleh melalui hidrolisis polisakarida dengan asam atau menggunakan bantuan enzim tertentu. Sepuluh sampel dari tiga belas buah dan sayuran di Thailand selatan dilaporkan sebagai sumber potensial prebiotik alami dengan kandungan oligosakarida tertinggi sekitar 9,81\% [6]. Akar chicory telah digunakan sebagai sumber alami inulin dan FOS dalam produksi komersial prebiotik. Hasilnya pun cukup tinggi berkisar antara $18 \%$ hingga $20 \%$. Oligosakarida campuran dari buah naga juga terbukti mampu mendorong pertumbuhan Lactobacillus dan Bifidobacteria [7].

Menurut Gibson dan Rastall secara umum oligosakarida dapat diperoleh melalui salah satu dari ketiga cara berikut : (1) ekstraksi langsung oligosakarida alami dari tumbuhan; (2) hidrolisis kimiawi polisakarida alam secara terkendali; dan (3) sintesis enzimatik menggunakan enzim hidrolase atau glikosil transferase. Hidrolisis secara kimiawi relatif mudah namun perlu optimasi kondisi [7].

Berdasarkan peluang tersebut, polisakarida yang berasal dari kulit singkong sangat berpotensi untuk dijadikan sebagai salah satu sumber alternatif yang ekonomis dalam memproduksi oligosakarida. Oleh karena itu perlu dilakukan penelitian terkait hidrolisis polisakarida dari kulit singkong, kondisi terbaik hidrolisis, serta produk yang dihasilkan dari hidrolisis polisakarida sehingga dapat menjadi acuan dalam pengembangan prebiotik.

\section{Metodologi}

\section{Alat dan Bahan}

Alat-alat yang digunakan dalam penelitian ini antara lain Beakerglass, magnetic stirer, dan blender. Selain itu, ada alat-alat yang digunakan untuk analisis kimia, yaitu tabung reaksi, spektrofotometer UVVisible, plat KLT silica gel $60 \mathrm{~F}_{254}$ (Merck Art 20-20 cm), dan bejana pengembang.

Bahan kimia yang dibutuhkan antara lain reagen DNS [dinitrosalycylic acid (DNS), $\mathrm{NaOH}, \mathrm{Na}-\mathrm{K}$ tartrat], fenol $5 \%(\mathrm{~b} / \mathrm{v}), \mathrm{H}_{2} \mathrm{SO}_{4}$ pekat, n-butanol, asam asetat, $\alpha$-difenilamin, aseton, asam fosfat, anilin, asam asetat, asam sitrat, asam klorida, dan asam sulfat.

\section{Preparasi Serbuk Kulit Singkong}

Kulit singkong diiris-iris kemudian dikeringkan terlebih dahulu selama 15 jam pada suhu $55-60{ }^{\circ} \mathrm{C}$. Kulit yang telah kering dihancurkan dengan blender hingga halus kemudian disaring dengan ayakan 30 mesh.

\section{Hidrolisis kimiawi}

Hidrolisis dilakukan dengan menggunakan pelarut asam. Asam yang digunakan adalah asam asetat, asam sitrat, asam fosfat, asam sulfat, dan asam klorida masing-masing dengan konsentrasi $0.3-0.7$ molar. Massa serbuk yang digunakan sebesar 20 gram dengan jumlah pelarut $100 \mathrm{~mL}$, dengan waktu hidrolisis selama 20 menit disertai dengan pengadukan $1000 \mathrm{rpm}$ menggunakan magnetic stirrer.

\section{Analisis Gula Pereduksi \& Gula Total}

Jumlah gula pereduksi yang terbentuk ditentukan dengan metode DNS. Sebanyak 1.5 
$\mathrm{mL}$ larutan standar glukosa dengan konsentrasi $50,100,150,200,250 \mathrm{ppm}$ yang telah diencerkan dari 1000 ppm dimasukkan ke dalam tabung reaksi dan ditambah $1.75 \mathrm{~mL}$ pereaksi DNS. Larutan standar dan sampel dimasukkan ke dalam waterbath $100{ }^{\circ} \mathrm{C}$ selama 20 menit kemudian didiamkan sampai suhu mendekati suhu ruang. Pengukuran absorbansi dilakukan pada panjang gelombang $540 \mathrm{~nm}$.

Analisis gula total dilakukan menggunakan metode phenol, dengan mereaksikan $0.5 \mathrm{~mL}$ larutan sampel dengan 0.5 $\mathrm{mL}$ larutan fenol dan $2.5 \mathrm{~mL} \mathrm{H}_{2} \mathrm{SO}_{4}$ pekat. Setelah itu diinkubasi selama 15 menit pada suhu ruang, kemudian dipanaskan di dalam penangas air pada suhu $40{ }^{\circ} \mathrm{C}$ selama 30 menit hingga terjadi perubahan warna. Hasil reaksi dibaca pada spektrofotometer dengan panjang gelombang $490 \mathrm{~nm}$.

\section{Analisis dengan KLT}

Secara kualitatif oligosakarida hasil reaksi hidrolisis dianalisis dengan kromatografi lapis tipis (KLT). Sampel hasil hidrolisis ditotolkan pada pelat KLT. Standar yang digunakan adalah glukosa (representasi monosakarida) dan maltosa (disakarida). Pelat KLT kemudian dimasukkan dalam bejana KLT dengan eluen n-butanol : asam asetat : air $2: 1: 1$. Reagen penampak, difenilamin-anilinfosfat, disemprotkan untuk menampakkan spot-spot pada pelat KLT. Pelat KLT dipanaskan pada suhu $100{ }^{\circ} \mathrm{C}$ selama 10 menit.

\section{Hasil dan Pembahasan}



Gambar 1. Limbah kulit singkong

Preparasi bahan baku diawali dengan reduksi ukuran kulit singkong dengan cara mengiris-iris dengan tujuan memperluas permukaan sehingga lebih mempercepat proses pengeringan (Gambar 1).

Pengeringan dilakukan menggunakan oven dengan suhu $55-60{ }^{\circ} \mathrm{C}$ selama 15 jam, Penggunaan suhu yang lebih tinggi dapat menyebabkan rusaknya senyawaan gula (karamelisasi) yang terkandung dalam kulit singkong. Limbah kulit singkong yang telah kering dihaluskan dengan menggunakan blender, untuk meningkatkan luas permukaan pada tahap hidrolisis menggunakan berbagai jenis asam (Gambar 2).

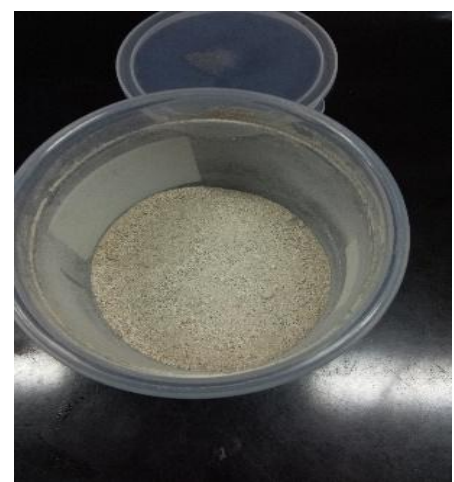

Gambar 2. Hasil blending kulit singkong

Kulit singkong yang telah dihaluskan selanjutnya diayak untuk mendapatkan ukuran yang homogen.

Hidrolisis polisakarida kulit singkong dilakukan menggunakan pelarut asam (Gambar 3). Hidrolisis dengan metode ini dapat menghasilkan oligosakarida maupun monosakarida. Penggunaan asam yang terlalu pekat akan menghasilkan produk yang homogen, yaitu berupa monosakarida saja.



Gambar 3. Proses pengadukkan kulit singkong pada hotplate

Setelah sampel kulit singkong dihidrolisis, proses selanjutnya ialah proses penyaringan dengan menggunakan kertas saring untuk memisahkan residu ekstrak berupa padatan dengan larutan yang mengandung oligosakarida terlarut. Proses ini dilakukan menggunakan peralatan berupa corong Buchner, Buchner flask, dan pompa vakum. Penggunaan peralatan tersebut untuk mempermudah dan mempersingkat waktu penyaringan di mana tekanan pada Buchner flask lebih rendah daripada tekanan atmosfer 
sehingga udara dari atmosfer akan mendorong larutan ke dalam Buchner flask.

Larutan ekstrak hasil penyaringan selanjutnya dinetralkan menggunakan sodium karbonat. Penggunaan sodium karbonat dapat mengurangi resiko terjadinya proses netralisasi dua kali menggunakan basa. Uji pH dilakukan menggunakan indikator universal hingga $\mathrm{pH}$ mencapai 7. Tujuan penetralan adalah agar proses hidrolisis tidak berlangsung berantai terhadap oligosakarida yang telah dihasilkan yang dapat menyebabkan perubahan semua produk menjadi monosakarida.

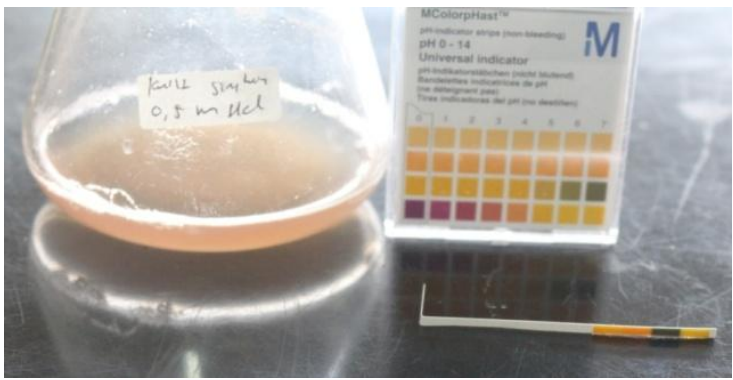

Gambar 4. Analisis pH penetralan

Sampel yang telah dinetralkan (Gambar 4) juga digunakan untuk penentuan derajat polimerisasi menggunakan spektofotometer dan uji menggunakan kromatografi lapis tipis (KLT).

Penentuan kadar gula total dilakukan dengan metode fenol. Metode dan reaksi pada metode fenol analog dengan uji Molisch. Penambahan asam sulfat pekat menyebabkan polisakarida terhidrolisis menjadi monosakarida yang kemudian terdehidrasi membentuk furfural. Furfural akan berikatan dengan 2 molekul fenol. Reaksi lebih lanjut akan menyebabkan terbentunya ikatan rangkap yang lebih terkonjugasi (Gambar 5). Hal ini mengakibatkan terbentuknya warna jingga yang menjadi dasar penentuan gula total secara spektrofotometri pada $490 \mathrm{~nm}$.

Rasio kadar gula total dengan gula pereduksi dapat digunakan untuk memprediksi derajat polimerisasi (DP) hasil hidrolisis. DP memberikan petunjuk awal tentang seberapa panjang rantai oligosakarida yang terbentuk dari hasil hidrolisis.

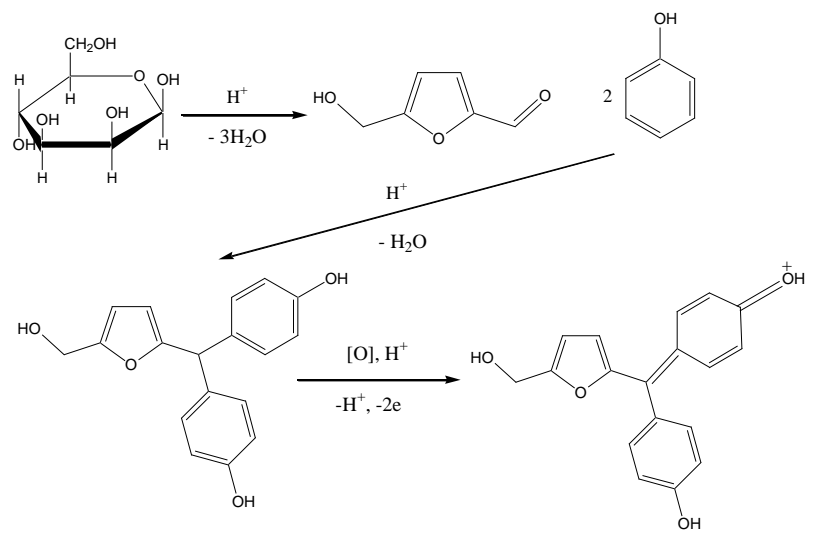

Gambar 5. Reaksi monosakarida dengan fenol pada suasana asam

Mayoritas hasil hidrolisis polisakarida kulit singkong menghasilkan DP 2-6 (Tabel 1). Hal ini mengindikasikan produk berupa oligosakarida telah terbentuk. Nilai DP oligosakarida adalah antara 2 hingga 9. Hidrolisis menggunakan asam dengan konsentrasi rendah menghasilkan produk dengan DP lebih besar dari 10.

Tabel 1. Derajat polimerisasi produk hidrolisis

\begin{tabular}{cccccc}
\hline \multirow{2}{*}{$\begin{array}{c}\text { Konsentrasi } \\
\text { (Molar) }\end{array}$} & $\begin{array}{c}\text { asam } \\
\text { asetat }\end{array}$ & $\begin{array}{l}\text { asam } \\
\text { sitrat }\end{array}$ & $\begin{array}{l}\text { asam } \\
\text { klorida }\end{array}$ & $\begin{array}{c}\text { asam } \\
\text { sulfat }\end{array}$ & $\begin{array}{c}\text { asam } \\
\text { fosfat }\end{array}$ \\
\hline 0.3 & 12.9 & 12.4 & 11.0 & 3.2 & 13.0 \\
0.4 & 2.8 & 6.3 & 2.7 & 3.0 & 4.2 \\
0.5 & 2.7 & 4.9 & 2.1 & 2.4 & 4.6 \\
0.6 & 2.7 & 4.4 & 1.8 & 2.3 & 2.7 \\
0.7 & 2.1 & 3.0 & 1.7 & 2.3 & 2.4 \\
\hline
\end{tabular}

Analisis nilai Rf dari spot-spot yang ada pada plat KLT dilakukan menggunakan perangkat lunak TLSee terhadap plat hasil hidrolisis dengan asam asetat (asam lemah) seperti pada Gambar 6, dan asam sulfat (asam kuat) seperti pada Gambar 7.

Glukosa dan maltosa digunakan sebagai standard relatif. Maltosa memiliki nilai Rf yang lebih kecil dari pada glukosa karena interaksi maltosa dengan silika lebih kuat. Rf glukosa sebesar 0,71 sedangkan Rf maltosa sebesar 0,64. Rf maltosa sangat berguna sebagai standar relatif untuk melakukan pendugaan produk oligosakarida. 


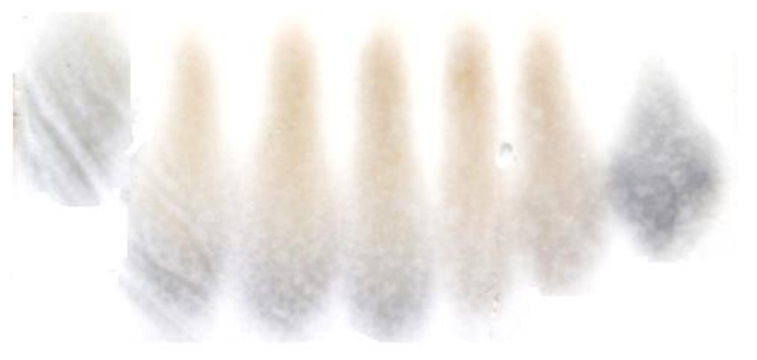

\section{G $\quad 0,7 \quad 0,6 \quad 0,5 \quad 0,4 \quad 0,3 \quad M$}

Gambar 6. Hidrolisis menggunakan asam asetat

Rf produk hidrolisis yang nilainya lebih besar, sama, ataupun berada di antara Rf glukosa dan Rf maltosa, kemungkinan besar adalah monosakarida. Produk hidrolisis yang diduga kuat sebagai oligosakarida adalah yang memiliki nilai $\mathrm{Rf}$ sama atau lebih kecil dari $\mathrm{Rf}$ maltosa. Tabel 2 menunjukkan bahwa hidrolisis menggunakan asam asetatmulai dari konsentrasi 0,3 molar hingga 0,7 molar tidak menyebabkan terbentuknya monosakarida. Rf produk yang lebih kecil daripada Rf maltosa (disakarida) mengindikasikan bahwa produk yang terbentuk minimal adalah dalam bentuk disakarida atau bahkan rantai sakarida yang lebih panjang.

Tabel 2. Rf oligosakarida hasil hidrolisis dengan asam asetat

\begin{tabular}{ccc}
\hline Kode & Spot & Rf \\
\hline $\mathrm{G}$ & Glukosa & 0.71 \\
$\mathrm{M}$ & Maltosa & 0.64 \\
0,3 & Asam asetat $0.3 \mathrm{M}$ & 0.57 \\
0,4 & Asam asetat $0.4 \mathrm{M}$ & 0.52 \\
0,5 & Asam asetat $0.5 \mathrm{M}$ & 0.50 \\
0,6 & Asam asetat $0.6 \mathrm{M}$ & 0.50 \\
0,7 & Asam asetat $0.7 \mathrm{M}$ & 0.54 \\
\hline
\end{tabular}

Gambar 7 menunjukkan plat KLT oligosakarida hasil hidrolisis menggunakan asam sulfat yang merupakan salah satu asam kuat. Spot yang dihasilkan menunjukkan pemisahan yang tidak sempurna, tampak seperti fenomena tailing. Hal ini sangat dimungkinkan oleh variasi produk dengan kepolaran yang hampir sama.

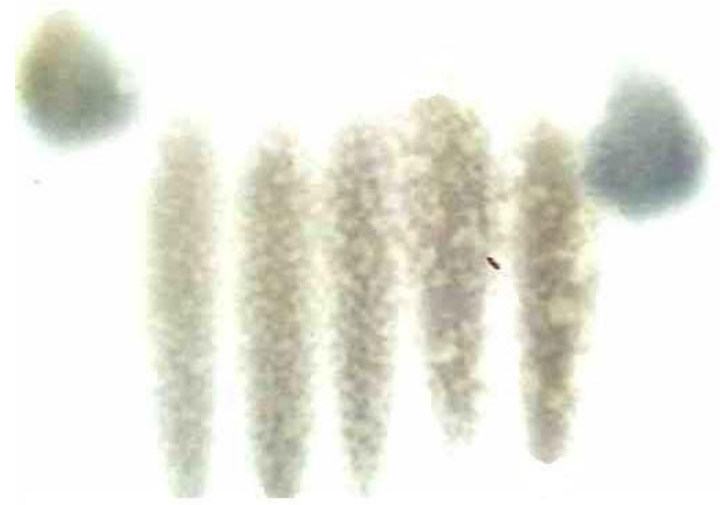

\section{G $\quad \begin{array}{llllll}0,3 & 0,4 & 0,5 & 0,6 & 0,7 & M\end{array}$}

Gambar 7. Hidrolisis menggunakan asam sulfat

Produk yang spot-spot-nya tidak terpisah tersebut juga mengindikasikan keberadaan senyawa golongan oligosakarida karena Rf yang dihasilnya lebih kecil dibandingkan dengan Rf maltosa yang merupakan disakarida (Tabel 3).

Tabel 3. Rf oligosakarida hasil hidrolisis dengan asam sulfat

\begin{tabular}{ccc}
\hline Kode & Spot & Rf \\
\hline $\mathrm{G}$ & Glukosa $(\mathrm{G})$ & 0.71 \\
$\mathrm{M}$ & Maltosa $(\mathrm{M})$ & 0.64 \\
0,3 & Asam sulfat $0.3 \mathrm{M}$ & $0.36-0.62$ \\
0,4 & Asam sulfat $0.4 \mathrm{M}$ & $0.32-0.59$ \\
0,5 & Asam sulfat $0.5 \mathrm{M}$ & $0.33-0.61$ \\
0,6 & Asam sulfat $0.6 \mathrm{M}$ & $0.38-0.63$ \\
0,7 & Asam sulfat $0.7 \mathrm{M}$ & $0.37-0.63$ \\
\hline
\end{tabular}

\section{Kesimpulan}

Hidrolisis limbah kulit singkong menggunakan asam lemah maupun asam kuat dalam berbagai konsentrasi dengan kondisi terkendali dapat menghasilkan oligosakarida. Rentang konsentrasi asam 0,4-0,7 molar menghasilkan produk dengan DP antara 2-6. Profil oligosakarida juga tampak berdasarkan nilai Rf yang dihasilkan.

\section{Saran}

Proses scale-up produksi oligosakarida dapat dilakukan menggunakan kromatografi kolom, sedangkan analisisnya dapat dilakukan dengan kromatografi cair kinerja tinggi (KCKT). 


\section{Ucapan Terimakasih}

Penulis menyampaikan rasa terima kasih kepada Lembaga Penelitian dan pengabdian kepada Masyarakat (LPPM) ITK yang telah memberikan banyak dukungan dalam penelitian ini.

\section{Daftar Pustaka}

[1] Badan Pusat Statistik. Luas Panen Ubi Kayu Menurut Provinsi (ha) 1993-2015, https://www.bps.go.id/dynamictable/2015 /09/09/879/luas-panen-ubi-kayu-menurutprovinsi-ha-1993-2015.html, diakses September (2018)

[2] F. Kusnandar. Kimia Pangan, Dian Rakyat, Jakarta (2010)

[3] A.L. Lehninger. Biochemistry, Worth Publisher, New York (2005)

[4] Haryati, T. dan Supriyati. "Pemanfaatan senyawa oligosakarida dari bungkil kedelai dan ubi jalar pada ransum ayam pedaging", JITV, 15.4 (2010): 253-260

[5] Syahruddin et. al. "Polisakarida Mannan Produk Samping Pembuatan Konsentrat Protein dari Bungkil Inti Sawit Sebagai Pengendali Eschericia coli (in vitro)", Prosiding Semnas Teknologi Peternakan \& Veteriner, (2008)

[6] S. Wichienchot, M. Jatupornpipat, R.A. Rastall. "Oligosaccharides of Pitaya (Dragon Fruit) Flesh And Their Prebiotic Properties", Food Chemistry, 120 (2009): 850-857

[7] G.R. Gibson and R.A. Rastall. Prebiotics: Development \& Application, John Wiley \& Sons, Chicester (2006) 